\title{
Paired Peer Learning through Engineering Education Outreach
}

Fogg-Rogers, Laura ${ }^{1}$; Lewis, Fay ${ }^{2}$; Edmonds, Juliet ${ }^{2}$

1 Science Communication Unit, University of the West of England, Bristol, UK

2 Department of Education, University of the West of England, Bristol, UK

Word Count: 6130

Corresponding author:

Laura Fogg-Rogers

Science Communication Unit, University of the West of England, UK.

Coldharbour Lane, Frenchay, Bristol. BS16 1QY.

+441173287602

Email: laura.foggrogers@uwe.ac.uk

This work was supported by the Engineering Professors' Council Public Engagement Awards. Our acknowledgement is given to Professor Penelope Harnett and Dr Catherine Hobbs for their help in planning this project. The authors disclose no conflicting interests or financial benefits resulting from this research.

Laura Fogg-Rogers is a Research Fellow in Science Communication at the University of the West of England, Bristol (UWE). Her research brings together engagement, involvement and learning through evaluating outreach and communication interventions. Laura previously worked as a journalist in the BBC and latterly as the Communications and Liaison Manager for the Centre for Brain Research, a neuroscience research centre at The University of Auckland in New Zealand.

Fay Lewis obtained a Ph.D in Phytopathology before becoming a primary school teacher for 15 years. During this time she led STEM subjects and projects in a variety of settings and delivered training to teaching practitioners. She is now a senior lecturer in Science, Maths and Design Technology Education in the Department of Education at UWE where she leads and develops STEM training.

Juliet Edmonds is a senior lecturer in Science Education in the Department of Education at UWE. She was an evaluator on the EU 'ENGINEER' education outreach project. She has been a Science and Technology educator for Primary and Early Years trainees for 20 years at Brunel University and UWE. Juliet has previously worked on a number of science curricula innovation projects. 
Abstract: Undergraduate education incorporating active learning and vicarious experience through education outreach presents a critical opportunity to influence future engineering teaching and practice capabilities. Engineering education outreach activities have been shown to have multiple benefits; increasing interest and engagement with science and engineering for school children, providing teachers with expert contributions to engineering subject knowledge, and developing professional generic skills for engineers such as communication and teamwork. This pilot intervention paired ten pre-service teachers and eleven student engineers to enact engineering outreach in primary schools, reaching 269 children. A pre and post longitudinal mixed methods design was employed to measure change in attitudes and Education Outreach SelfEfficacy in student engineers; alongside attitudes, Teaching Engineering Self-Efficacy and Engineering Subject Knowledge Confidence in pre-service teachers. Highly significant improvements were noted in the pre-service teachers' confidence and selfefficacy; while both the teachers and engineers qualitatively described benefits arising from the paired peer mentor model.

Keywords: Active Learning, Teacher Training, Women in Engineering, Peer Learning/Teaching, Science Education

\section{Introduction}

This paper describes the development and piloting of a model of collaborative active learning in Higher Education (HE), through pairing student engineers and pre-service teachers to mentor each other to deliver engineering education outreach activities.

Education outreach is one form of public engagement utilised by engineers (students or professionals) to influence learning and attitudes in Science, Technology, Engineering, and Mathematics (STEM) education (Jeffers, Safferman, and Safferman 2004; FoggRogers, Wilkinson, and Weitkamp 2014).

By engaging with schools and communities, engineers can increase children's interest and engagement with STEM subjects and also change their views of scientists and engineers (Wilkinson and Sardo 2013), while teachers also value expert contributions to STEM knowledge (Laursen et al. 2007). Attitudes at primary (elementary) school in particular can influence later interest in STEM, especially for girls who develop their gender identity and consequently the appropriateness of STEM as a career before entering secondary school (aged 11 in the UK) (EngineeringUK 2015; Archer et al. 2012; Murphy and Whitelegg 2006). Several education outreach programmes have shown specific improvements in children's attitudes towards engineering (Louis S.Callahan 2011; Stapleton et al. 2009; Molina-Gaudo et al. 2010), along with stable (not declining) recruitment to local engineering HE programmes (Davis, Yeary, and Sluss 2012; Martínez-Jiménez et al. 2010). 
Education outreach has also been found to benefit engineers themselves, enabling the development of generic skills such as communication and teamwork, required in professional environments (Pickering et al. 2004; Direito, Pereira, and Duarte 2012). Alongside this, policy and funding changes are encouraging engineers to communicate their work as part of the Public Engagement with Science (PES) agenda (RCUK 2010; Stilgoe, Lock, and Wilsdon 2014; Palmer and Schibeci 2012) and the drive to widen participation and diversity in engineering careers (Perkins 2013; EngineeringUK 2015). As such, it is becoming increasingly important that student engineers gain opportunities to practise their public engagement and education outreach skills within engineering $\mathrm{HE}$, before entry to the workplace.

\subsection{Active learning through engineering education outreach}

In this context, 'active learning' is used to describe educational approaches which enable students to actively pursue learning outcomes; gaining a deeper understanding of the skills and content required by "deliberately testing those models to determine whether they work, and then repairing those that seem to be faulty" (Michael and Modell 2003: p160). Active learning approaches have been found to improve performance on STEM courses by increasing the understanding of content, developing skills in critical thinking and communication, and correcting misconceptions which may have arisen through traditional teaching methods (White et al. 2015; Freeman et al. 2014; Michael 2006).

We propose that engineering education outreach programmes enable engineers and other participants, such as children and teachers, to experience active learning through taking part in hands-on activities and problem solving, then later synthesising this learning through further discussions and evaluation. Inclusion of education outreach in HE engineering education programmes would enable student engineers to develop higher-order thinking skills such as analysis, synthesis, and evaluation (Krathwohl 2002), alongside generic skills such as communication and teamwork (Direito, Pereira, and Duarte 2012). We propose the key learning opportunity is provided by student engineers being positioned as 'experts', communicating engineering concepts to audiences less knowledgeable than themselves (children and teachers) (Pickering et al. 2004; Owen and Hill 2011). Alongside this, working with the community acts as service learning (Duffy et al. 2008; Oakes et al. 2002), which enhances the employability of student engineers through working towards professional codes such as the UK Standard for Professional Engineering Competence (UK-SPEC) or professional status awards such as Chartership (Owen and Hill 2011).

In the context of the primary school classroom 'active learning' for children is said to develop from active engagement in the learning process (Hewitt and Tarrant 2015). In this way children are able to engage in individual ways with the learning and use their preferred way of thinking, resulting in shared meaning making and knowledge 
construction (Cooper 2014). The model of engineering education outreach used in this project enabled children to move around, talk, use resources, and problem solve collaboratively, therefore encouraging dialogic learning through the sharing of experiences and understanding of STEM concepts throughout the Engineering Design Process.

This is important for future STEM progression, as the way science is taught in primary and secondary schools has been identified as a contributing factor in the declining interest in STEM subjects at HE level, which is critical for continuation into many STEM careers (Rocard et al. 2007). This lack of enjoyment and consequent low uptake in HE has been variously ascribed to perceptions of the subjects as being difficult, gender bias in curricula which are less interesting to girls, teacher expertise, and pedagogical approaches (Rocard et al. 2007). An inquiry-led, active learning approach can motivate learners and help them to achieve many of the end goals of science education (Madhuria, Kantamreddi, and Prakash Gotetib 2012). However, in order for such an approach to be successful, teachers need not only to have robust levels of subject knowledge but to also have confidence in their subject knowledge (Chue and Lee 2013).

\subsection{Perceived self-efficacy in pre-service teachers and student engineers}

Primary school teachers are seldom science or technology specialists; in the UK only $5 \%$ of primary teachers have a science related degree (Department for Education 2013) leading to concerns over teachers' science subject knowledge, particularly in the physical sciences (Murphy and Whitelegg 2006; Royal Society 2010). Although subject knowledge is not seen as essential for effective pedagogy, a lack of confidence and understanding can result in didactic, 'cautious' teaching (Neale, Smith, and Johnson 1990) as teachers do not feel comfortable when teaching STEM subjects (Bleicher and Lindgren 2005). . Conversely, improvements in teachers' attitudes to a subject can lead to a positive impact not only on children's performance but also on their engagement and enjoyment (Ofsted 2011). This highlights the importance of addressing and positively influencing pre-service teachers by cultivating positive dispositions and beliefs towards subjects such as science and engineering during their training (Jung and Rhodes 2008), through opportunities to reflect on experience and practice in schools (Flores and Day 2006).

The psychological concept of Perceived Self-Efficacy (PSE) is a way to measure this belief of a person to in their own ability to perform specific actions, and it reflects a perception of capability rather than measuring actual performance (Gonzalez, Goeppinger, and Lorig 1990; Bandura et al. 2008). PSE is determined by innate capabilities (Declerck, Boone, \& De Brabander, 2006), personal performance, and vicarious experience (Bandura, 1997), and can be influenced by experience of success, social modelling, and social persuasion (Bandura, 2004). Studies have indicated a link between PSE and teacher performance (Bates, Latham, and Kim 2011; Mcmullan, Jones, and Lea 2012). Consequently, teacher PSE in science and engineering may well 
influence children's attitudes, achievement, and motivations (McKinnon and Lamberts 2013), along with teachers' willingness to adopt innovative teaching strategies, time spent on teaching certain subjects, cultural competence, alternative conceptions of science, and classroom management beliefs (Flores and Day 2006).

In parallel, higher PSE has been shown to be related to positive outcomes in studying and pursuing careers in non-traditional fields, which is important for girls/women and people from Black and Minority Ethnic backgrounds in engineering (Marra et al. 2009). Research with successful people in STEM indicates that mastery experience was the primary source of men's PSE beliefs, while social persuasion and vicarious modelling are important for women (Zeldin, Britner, and Pajares 2008). We propose it is therefore important for student engineers to both trial new experiences (experiencing mastery) and watch peers do the same (experiencing social persuasion and vicarious modelling) in order to improve PSE in engineering education outreach capabilities. In parallel, teachers and children may improve PSE in studying STEM subjects, presenting a critical opportunity to influence future capabilities for STEM teaching and studying success.

\section{Methodology}

This pilot study aimed to evaluate any potential impact of a novel paired peer mentor approach to engineering education outreach in primary schools, assessing if the pairing of student peers undertaking active learning is of benefit and possible reasons why this may be so. By pairing pre-service teachers (Initial Teacher Education - BA teaching degrees) and student engineers (BEng and MEng), the aim was for the engineers to mentor and improve the pre-service teachers' subject knowledge confidence and PSE for STEM subjects, while the pre-service teachers would mentor and improve engineering students' public engagement and communication generic skills, along with their PSE for engineering outreach. Through delivery into primary schools, the intervention aimed to improve attitudes and attainment in STEM for young children aged 8-11 years, ultimately aiming to improve the age and gender mix of those participating in engineering. See Figure 1 for a representation of the intervention process. The following sections will describe the methodology of the intervention design, and the evaluation protocols.

\subsection{Paired Peer Mentors Intervention}

Two international engineering education outreach programmes formed the basis for the resources for this intervention, namely the US 'Engineering is Elementary (EiE)' (Cunningham 2009) and the European Union 'brEaking New Ground IN the sciencE Education Realm' (ENGINEER) (ENGINEER 2015) projects. Both programmes have been extensively evaluated and have shown that boys' and girls' perceptions of 
engineering and technology, their understanding of engineering, and their understanding of relevant science, are greatly improved through participation (Lachapelle et al. 2010; Cunningham, Lachapelle, and Hertel 2012). The programmes use context-based stories about different engineering disciplines to enable primary school children (aged 8-11, UK Upper Key Stage 2) to explore a problem and undertake inquiry-based science education. As these programme resources have been shown to be effective, this current project was able to focus on evaluating the impacts of pairing the student engineers and pre-service teachers to deliver these resources.

\subsubsection{Education outreach resources}

This intervention utilised the EU ENGINEER design challenges which are freely available on the project website (ENGINEER 2015). The EU ENGINEER programme material was screened for modules which suited the skills of the student engineers at the University of the West of England, Bristol (UWE) (Mechanical Engineering and Aeronautical Engineering), while also appealing to primary school children at Key Stage 2. Five key modules were chosen (Balance and Force, Electricity, High Flyers, Mechanics, and Sinking and Floating) on the basis of the suitability for the curriculum requirements of the schools involved in the project. The resources and teaching sheets which are available on the EU ENGINEER website (ENGINEER 2015) were assembled by the project team.

\subsubsection{Intervention methods}

Four local primary schools were recruited into the project; this gave access to ten classes of primary school children. The project then aimed to recruit ten undergraduate student engineers and ten undergraduate pre-service teachers at UWE; the project aims can be seen in Table 1. Ethics consent was received from the University of the West of England Research Ethics Committee. Notices were sent to all students in Year Two of their courses, and short information seminars were given in lectures. Interested students contacted the project team and were sent Participant Information Sheets; students who subsequently volunteered for the project signed consent forms.

Following completion of the recruitment phase, an afternoon training session was conducted by the project team, explaining the necessary project skills, and introducing the student paired peer mentors to each other and the EU ENGINEER resources. Initially the two groups of students were separated. The pre-service teachers were given training about the Engineering Design Process and the role of engineers, and how this could link to the UK science curriculum. During this time the student engineers received training in education outreach skills when working with children, with a focus on inquiry-based science education, using questioning as a tool for learning. 
The schools had previously chosen the EU ENGINEER challenge that they would like their children to undertake based on curriculum demands, and the engineers were matched to the schools/engineering challenge on the basis of this and their particular field of expertise. The pre-service teachers were then paired with the school and student engineer based on their preferred choice of EU ENGINEER challenge.

The next stage of the training was to outline the structure, purpose and plan for the project to the whole group. The unit structure of the EU ENGINEER challenges was explained, as well as the research processes and aims of the project. The pairs of students then worked together on the EU ENGINEER challenges for approximately two hours. During this time they were able to familiarise themselves with the materials and work through the challenge. This enabled the student engineers and project leaders to provide support to the pre-service teachers about the underlying science behind the modules, and the pre-service teachers to provide support and to lead the planning for how this would be taught and communicated to the children when in school.

The paired pre-service teachers and student engineers were then requested to meet independently to further plan their lessons and teaching arrangements for the primary school visits. The school visits took place over two consecutive weeks, with one full day and one further half day spent in the classroom. The school work was observed by the project team and supervised by existing primary school teaching staff to inform the project. The school children and the paired peer mentors worked towards presenting the results from their engineering challenges at a subsequent Researching Conference.

The final Researching Conference was held at UWE in the fourth week of the project, and aimed to showcase research and cutting-edge engineering taking place in HE, thus exposing the children to a university environment. The conference also enabled feedback between children working in different schools at the end of the project. The children presented their challenge outcomes in the scientific conference format (poster, exhibition or table-top PowerPoint presentation), providing opportunities for them to communicate their understanding of the scientific process. Their student paired peer mentors were also present to provide feedback and support the children through this process. A full toolkit of the timetable for this project has been published separately (Fogg-Rogers, Edmonds, and Lewis 2015).

\subsection{Study design}

The evaluation was conducted as a pre and post longitudinal design over the length of the project, with mixed methods data triangulated from the three participant groups (student engineers, pre-service teachers, and children). School children also received Participant Information Sheets and signed consent forms; participation was voluntary, with data grouped and anonymised for reporting. 


\subsubsection{Data collection and questionnaire design}

The pre-service teachers and student engineers completed several questionnaires pre and post their participation in the intervention. As well as questionnaires about their prior experience, questionnaires were also designed to assess their PSE to carry out several aspects of participation:

a) Project feedback questionnaires were designed to ascertain the demographic particulars, prior experience, and attitudes (Likert quantitative scales) of preservice teachers and student engineers to the project. Open responses (qualitative) were also invited to gain the participants own views about their progression in generic skills such as communication and teamwork, and their confidence in subject knowledge or engineering outreach.

b) Quantitative PSE scales were designed to assess the pre-service teachers' PSE for their teaching of science and engineering i.e. their confidence in their ability to teach these subjects to bring about favourable outcomes for the children. These were named the 'Revised Teaching Engineering SelfEfficacy' scale (TESS-R) (defined as the personal belief of teachers in their abilities to positively affect children's educational attainments in engineering) and the 'Engineering Subject Knowledge Confidence' scale (ESKCS) (defined as their personal confidence in their knowledge of engineering as a topic). These were designed according to the principles described by Bandura (2006) and based on questions from the STEBI-B (Bleicher 2004) and TESS scales (Yoon, Evans, and Strobel 2012). The TESS-R scale featured seven questions asking for agreement about confidence in their engineering teaching skills rated on a 10 point scale; the ESKCS featured eleven questions asking for agreement about confidence in their engineering subject knowledge rated on a 10 point scale. Scale results were determined by taking a mean of the ratings for all the questions to produce one overall value per scale.

c) A quantitative PSE scale was also designed to assess the student engineers' 'Engineering Outreach Self-Efficacy' (EOSS) (defined as the personal belief of engineers in their abilities to positively affect children and teachers' learning (including interest and attitudes) in engineering). The questionnaire was designed following the principles described by Bandura (2006) and based on questions from the TESS scale (Yoon, Evans, and Strobel 2012). This scale featured 12 questions asking for agreement about confidence in their education outreach skills rated on a 10 point scale. The scale result was determined by taking a mean of the ratings for all the questions to produce one overall value for the scale. 
Reflective diaries following the training sessions and experiences in school were also invited to capture qualitative responses to the overall project, their partner's participation, and the children's reaction to the project. School children provided feedback on the project, their attitudes to STEM subjects, and attitudes to engineering as a career, using pre and post paper questionnaires administered in the classroom; this data will be reported elsewhere.

\subsubsection{Data Analysis}

Quantitative questions were analysed using descriptive statistics in Microsoft Excel and then analysed where appropriate using non-parametric statistical tests in SPSS v10. The questionnaire responses from the student engineers and pre-service teachers were compared with Mann-Whitney U tests, while the respective PSE scale results from the student engineers and pre-service teachers were compared over time (pre and post) using Wilcoxon Signed Rank tests. Qualitative responses were analysed separately by two of the project researchers using Thematic Analysis (Braun and Clarke 2006) in QSR nVivo 10. Using a process of inter-coder constant comparison, thematic hierarchies were combined so that the responses from the pre-service teachers and student engineers could be triangulated into one coding frame.

\section{Results}

\subsection{Participant Characteristics}

Eleven student engineers were recruited to the project, all from Year Two of their courses. Seven of the engineers were undertaking BEng degrees in Aeronautical Engineering, while four were undertaking BEng degrees in Mechanical Engineering. Two of the students were female. The students were from a diverse mix of ethnic backgrounds. These results can be seen in Table 3. None of the students had undertaken public engagement in schools before, and only two had taken part in any other form of public engagement (departmental open days). Less than half of the engineers (45\%) felt 'fairly well equipped' to undertake public engagement. One of the students did not complete post questionnaires but his qualitative data is still included.

Ten pre-service primary teachers were recruited to the project; all were enrolled in a three year Initial Teacher Education (ITE) undergraduate degree. Nine were in their second year of study and one was in their third year; all were female. They had received training on scientific thinking and process as part of their first year studies and were also undertaking further science knowledge and pedagogy courses as part of their second and third year studies. Roughly half of the participants had opted to take a further module specialising in maths and science in their second year, with the others specialising in Special Educational Needs, Art and Design, Languages and also Steiner Education. All had at least two months' previous teaching experience in a primary school setting. These results can be seen in Table 3 . 
Four schools were recruited to the project, each involving a variety of classes and numbers of children; in total 269 school children were involved in the project. These results can be seen in Table 4 .

\subsection{Overall feedback}

There were no significant differences between how the student engineers and preservice teachers rated the project - all rated that overall it was a success. In examining how well the project 'met their needs and expectations', student engineers rated the project (mean) as 4.2 out of $5(S D=0.8)$, while the pre-service teachers rated it as 4.6 out of $5(S D=0.5)$ with no significant differences (Significance level taken throughout as the 0.05 threshold; here $p=0.09$ ). Overall the cohort mean rating was 4.4 out of 5 $(S D=0.7)$. Enjoyment of the project $(M=4.5, S D=0.6)$ and the usefulness of working with a partner $(M=4.9, S D=0.4)$ were rated particularly highly, as can be seen in Figure 2. The proportion of student engineers who thought they were now 'fairly well equipped' to undertake public engagement following the intervention rose from $45 \%$ to $64 \%$ - this was a $42 \%$ increase. Additionally, $70 \%(N=7$ out of 10$)$ of the engineers indicated that they thought they are now likely to be 'more active' in public engagement.

Qualitative data indicated that the engineers were motivated to take part in the project as they saw it as a way to improve their communication skills for their future career. They also reflected about how much they had learnt through being forced to communicate their engineering disciplinary knowledge at a simple level.

Engineer 6: I found this project to be tremendously enjoyable and challenging; it forced me to re-evaluate my understanding of mechanical principles so that I could break the subject matter down into lessons that make sense to people.

Engineer 8: I thoroughly enjoyed myself during this project. It made me realise that teaching isn't an easy job and how much effort is required to plan even an hour of teaching. Also it was a great experience to work with school students and I got an insight into their idea of engineering.

Engineer 3: Acquiring new skills. Inspire the younger generation into engineering. Improve my CV and chances of employment.

The engineers also reflected on the need to inspire younger generations about the possibilities and potential offered by engineering; as both a STEM subject and as a potential career open to everyone.

Engineer 9: I've really enjoyed this project because not only did I feel like I was teaching a class, I felt like I was teaching a generation. 
Engineer 4: I think it is important children understand what engineering is, so that they don't miss the path to a future they may have wanted.

Engineer 2: The objective of the project is good, as more children could be inspired to go into something engineering/science based.

The pre-service teachers reflected on how the project enabled the children to experience engineering and its application in real life. They indicated that they enjoyed participating in the project, found it rewarding in terms of their own learning, and also felt it would have an impact on their future teaching.

Teacher 3: I feel the Engineering Design Process is a useful model to base my teaching on. I think that it is very good for children's development and learning in science, as science should be practical.

Teacher 7: I am excited and confident that I can effectively give pupils motivation. It is an interesting and engaging way to teach science.

Teacher 9: I feel now that I would be able to teach an engineering session using the resources available (e.g. plans) through this project, linking to the National Curriculum.

\subsection{Paired peer mentor model}

The quantitative data indicated that working in a partnership was rated as one of the most rewarding aspects of the project $(M=4.9$ out of $5, S D=0.4)$. The qualitative open questions and reflective diaries provided further insights into why this was so; namely that the paired peer mentoring enabled active learning between the partners. As the student engineers and pre-service teachers had complementary skills and knowledge, they were able to exchange these with each other and learn from the other's expertise.

Teacher 4: I think the combination of pairing engineers and teachers for this activity works well.

Engineer 10: Working in a pair was very helpful. There were instances where my engineering knowledge was necessary to speak to the class and equal instances where my partner helped knowing how to speak to the children, control the class etc.

Engineer 4: It was interesting working with a partner student; I haven't done this before whilst at university. If I were to have taken the class by myself it would have been very stressful; by working in a pair we are able to lean on each other and give ourselves the chance to breathe a little. 
The student engineers indicated that they appreciated working in partnership to learn from the pre-service teachers' organisation and communication skills, thereby developing their generic skills.

Engineer 6: I was given advice on talking to the children in a manner that they can engage with, for example being careful with my vocabulary and using smaller succinct sentences.

Engineer 2: My teaching partner and I were very happy with the whole experience. Teaching partner was excellent at encouraging the class, and making sure the day was going to schedule.

In parallel, the pre-service teachers asserted that they had benefitted from the student engineers' subject knowledge, through sharing knowledge with an 'expert' peer.

Teacher 10: It was useful having an engineer during certain aspects of the teaching lesson, as he was able to explain the scientific terms regarding forces like: lift, weight, mass and thrust. He also supported the children's knowledge during the testing stage as he would say to the children whether more/ less weight needed to be added.

Teacher 9: I was very relieved to have my partner in the classroom when the children started to ask questions.

Teacher 2: My partner and I worked well together and I felt that it helped because it meant that as he was an engineer, any knowledge needed to help describe the activity could be shared; so I would explain the task and what would need to be done and he could go into more detail about some of the technical parts.

Teacher 7: I found it very interesting and also beneficial to learn and also to work with an expert.

\subsection{Perceived self-efficacy and subject knowledge confidence}

The mean Education Outreach Self-Efficacy scale (EOSS) value for the student engineers did not significantly change over the course of the intervention (observed test value is reported as $Z$ throughout; here $Z=-0.48, p=0.64$ ). Before the project the mean 
PSE value was 7.9 out of $10(S D=1.2)$ and following the project the mean value was $8.0(S D=1.1)$.

The mean Teaching Engineering Self-Efficacy (TESS-R) value for the pre-service teachers significantly increased over the course of the intervention $Z=-2.81, p=0.005$; before the project the mean PSE value was 4.1 out of $10(S D=0.9)$ and following the project this had increased to $7.8(S D=0.4)$.

The mean Engineering Subject Knowledge Confidence (ESKCS) value for the preservice teachers significantly increased over the course of the intervention $Z=-2.81, p=$ 0.005; before the project the mean value was 3.3 out of $10(S D=1.8)$ and following the project this had increased to $7.3(S D=0.9)$. All these results can be seen in Figure 3.

Analysis of qualitative data revealed that confidence in their subject knowledge was a commonly occurring theme amongst the pre-service teachers. Prior to the intervention, the pre-service teachers indicated a lack of confidence in their science and engineering subject knowledge.

Teacher 7: I am anxious about subject knowledge, how in depth could I answer questions.

Teacher 10: I need to gain more experience in teaching science so I know how to better answer questions.

Teacher 5: I am excited but apprehensive about certain concepts arising that I may not be so confident answering.

Teacher 9: I enjoy teaching science, however a lot of questions arise that need a lot more subject knowledge than I have.

Following the project, qualitative data from the pre-service teachers reinforced the quantitative data, and indicated an increase in their confidence about their engineering subject knowledge and their PSE to teach STEM subjects.

Teacher 1: Much more confident with knowledge and having a successful engineering lesson.

Teacher 9: This project has made me more confident in my subject knowledge and explanations in terms of engineering.

Teacher 2: I think that by following the Engineering Design Process I will be confident enough to teach it to my primary age children. 
Teacher 3: I feel excited and much more confident. I think inquiry based learning makes it much more accessible and contextual to children's learning.

In Figure 4 the relative sizes of the words relates to the frequency that they were selected by the pre-service teachers to report their feelings towards the teaching of science and engineering. It appears that initially this was seen as fascinating and challenging but also frightening, complex and in some cases daunting. After participation in the project, teaching science and engineering was still viewed as challenging but this was not so dominant, with words such as exciting, rewarding, and important also being highly favoured. Indeed, $80 \%(N=8$ out of 10$)$ of the pre-service teachers who participated stated that they would undertake similar work with children in the future.

\section{Discussion}

This paper describes the pilot evaluation of a new model to incorporate service and active learning about engineering education outreach into engineering and pre-service teaching undergraduate HE courses. Utilising existing outreach resources (ENGINEER 2015) meant that the intervention focussed on evaluating the benefits of pairing student peers, with the aim of student engineers mentoring pre-service teachers in engineering subject knowledge, and pre-service teachers mentoring student engineers in generic skills such as communication and teamwork.

\subsection{Active learning through engineering education outreach}

The student engineers and pre-service teachers reviewed the project positively, rating it highly for enjoyment and for meeting their needs and expectations. The student engineers qualitatively stated that they had learnt a lot about teamwork and communication through participation in these hand-on activities. An unexpected benefit was also found in communicating disciplinary engineering concepts to less knowledgeable audiences, as the engineers indicated that it actually consolidated their own learning. Indeed, the student engineers were positioned as engineering experts within the paired peers and classrooms, which proved to be a vital active learning experience. The student engineers did not show an improvement in their PSE for engineering education outreach; however as these participants volunteered for the project, they may already have had high levels of PSE for education outreach and public engagement.

The engineers did show an improvement in their perceived level of skills, with a $42 \%$ increase in the proportion who felt they were now 'fairly well equipped' to undertake public engagement; over two-thirds (64\%) of the engineers gave this rating following the project. Additionally, $70 \%$ of the engineers indicated that they thought they are now likely to be 'more active' in public engagement; while the remaining $30 \%$ indicated 
they would continue at the same level of engagement. It is assumed that the participants were already interested in public engagement as they volunteered for this project, so any improvement in perceived skills and interest has been taken as a success.

This indicates that the project provides both mastery experience and vicarious modelling (Bandura 1997) which are important for men and women's respective PSE and subsequent success in STEM (Zeldin, Britner, and Pajares 2008). Consequently the intervention may boost engineers' generic skills and involvement in public engagement throughout their career (Pickering et al. 2004; Direito, Pereira, and Duarte 2012), contributing towards societal aims to improve understanding and attitudes towards engineering (National Coordinating Centre for Public Engagement 2010; EngineeringUK 2015; Engineering Professors' Council 2014).

There were highly significant increases in the pre-service teachers' engineering subject knowledge confidence levels as well as PSE for teaching engineering following the intervention. Bandura (1997) suggests that PSE may be most amenable to change during early learning; indicating that teachers' beliefs and PSE are therefore potentially the most susceptible to influence and change during their initial training (Flores and Day 2006). Participating in this intervention early in a teaching career could be crucial in shaping dispositions towards STEM subjects and engineering careers in the future; with improved PSE and subject knowledge being linked to improved teacher performance (Bates, Latham, and Kim 2011; Mcmullan, Jones, and Lea 2012). Woolhouse and Cochrane (2009) suggest that teacher professional development which provides a sound grounding in subject specific knowledge but also actively engages individuals with their training benefits the teachers, their school children, and the schools, and changes teachers' attitudes towards their teaching. Indeed, $80 \%$ of the pre-service teachers in this study stated that they would undertake similar work with children in the future.

\subsection{Paired peer mentor model}

The paired peer mentor model was rated very highly in the project feedback.

Qualitatively, the student engineers stated that they had learnt from the organisation and communication skills of the teachers. They were also proud to have passed on some of their science and engineering subject knowledge and enthusiasm to the pre-service teachers and children, which they felt would influence future generations, as indicated in other literature (Fogg-Rogers, Wilkinson, and Weitkamp 2015). The paired peer mentor model was also positively reviewed by the pre-service teachers, with many qualitatively stating that they had learnt from the science and engineering subject knowledge of the engineers. Many of the pre-service teachers thought that this 'expert' knowledge had also benefitted and influenced the children in their class.

It would thus appear that the collaborative 'paired peer' element has been a significant factor in the success of this pilot project. Peer coaching, such as that used within this study, may have a great impact as it discourages practitioners from working in isolation 
and instead encourages discussion (Van Driel, Beijaard, and Verloop 2001); which is a key component for active learning. Collaborating with an 'expert engineer' whilst working through the EU ENGINEER materials appeared to open up dialogue for the pre-service teachers about not only the Engineering Design Process involved but also the science behind the project, enabling active learning to boost their confidence in their subject knowledge and PSE to teach engineering. The positive impact of collaborative work may also emerge from the emotional support that peers provide (Mintzes et al. 2012). Van Driel et al (2001) noted that professional development for teachers may be particularly effective when conducted with peers rather than through a top down approach. It may therefore be that it is not only the 'paired' element of this work which is important but also the 'peer' element. 


\subsection{Limitations}

Despite the potential positive impacts that participation in the pilot project may have brought to the pre-service teachers and student engineers, there must remain a note of caution. Due to the low numbers involved, our findings should be addressed with caution and it may be that a longer-term and larger scale programme and evaluation would be needed to potentially bring about significant and long-term change in student engineers' and pre-service teachers' practical knowledge and PSE. Indeed, it cannot be assumed that changes in confidence in subject knowledge or PSE will have led to improved pedagogical knowledge for pre-service teachers and it must also be remembered that inconsistencies often occur between teachers' expressed beliefs and their behaviour in the classroom (Van Driel, Beijaard, and Verloop 2001). Other embedded factors in the project may have contributed to increasing teaching participants' overall teaching confidence; peer support, social interaction, positive feedback from the children, increased security in subject knowledge, collaborative planning, use of materials, and engaging in reflective activities. It must also be noted that perceived improvements cited by the student engineers to generic skills such as communication and teamwork were self-reported, and were not verified externally or quantitatively. It would be interesting to repeat this pilot evaluation with a larger cohort of participants over a longer period of time to verify the results.

\section{Conclusion}

This pilot paired peer mentoring model of engineering education outreach in primary schools appears to have been a successful active learning experience for both the student engineers and pre-service teachers involved. The highly significant improvements in pre-service teacher PSE and subject knowledge confidence for engineering indicated a potential positive improvement in teacher performance for their future careers, and consequently future improvements in children's attitudes and attainment in STEM. Qualitative data indicated that student engineers improved their communication and teamwork soft skills through active learning during education outreach.

It would appear that working alongside a peer with complementary skills and expertise is an important factor in enabling these benefits. Engineering education outreach focussing on mentoring pre-service teachers is therefore valuable for engineers to influence societal attitudes and attainment in STEM, alongside improving their own generic skills for career development. A toolkit of the resources and methods used has thus been created for other engineering HE courses (Fogg-Rogers, Edmonds, and Lewis 2015). We conclude that the paired peer mentor model is therefore worthy of further research to investigate the incorporation of this active learning intervention into $\mathrm{HE}$ undergraduate curricula. 


\begin{tabular}{|l|rl|}
\hline Paired Peers & Aims & \\
\hline Student & $\bullet$ & $\begin{array}{l}\text { Share their expert knowledge through collaboration with pre- } \\
\text { engineers }\end{array}$ \\
& service teachers who may not have a science or engineering \\
& background, enabling improved future teaching of STEM. \\
& $\begin{array}{l}\text { Develop creative activities that enable them to communicate in } \\
\text { new ways (adapting complex specialist knowledge), and to reach } \\
\text { new audiences in engineering public engagement (primary } \\
\text { school communities). }\end{array}$ \\
& $\begin{array}{l}\text { Change attitudes and attainment in STEM for Key Stage 2 } \\
\text { children, ultimately attracting more young people, particularly } \\
\text { girls/women and those from BME backgrounds, into } \\
\text { engineering. }\end{array}$ \\
\hline Pre-service & $\begin{array}{l}\text { Gain increased awareness, understanding and confidence in } \\
\text { STEM subjects through working with the paired engineers, } \\
\text { enabling future exciting and relevant learning opportunities in } \\
\text { their professional classrooms. } \\
\text { Develop creative activities to provide learning experiences for } \\
\text { Key Stage 2 children in engineering, enriching the STEM } \\
\text { curriculum. }\end{array}$ \\
\hline
\end{tabular}


Table 2: Coding Framework for Analysis of Qualitative Data from Student Engineers and Pre-Service Teachers

\begin{tabular}{|l|l|l|}
\hline Theme & Code & References \\
\hline $\begin{array}{l}\text { Personal } \\
\text { development }\end{array}$ & Improved skills & 16 \\
\cline { 2 - 3 } & Opportunities for further engagement & 3 \\
\hline \multirow{2}{*}{$\begin{array}{l}\text { Reflections on } \\
\text { the project }\end{array}$} & $\begin{array}{l}\text { ENGINEER materials (not covered in } \\
\text { this paper) }\end{array}$ & 25 \\
\cline { 2 - 3 } & Paired peers' enjoyment & 17 \\
\hline \multirow{2}{*}{$\begin{array}{l}\text { Working in } \\
\text { partnership }\end{array}$} & Comments on the engineers & 12 \\
\cline { 2 - 3 } & Comments on the partnership & 19 \\
\cline { 2 - 3 } & Comments on the teachers & 11 \\
\hline
\end{tabular}


Table 3: Characteristics of the Students Involved in the Paired Peer Mentors Project

\begin{tabular}{|c|c|c|c|c|}
\hline Student & Specialism & Age & Gender & Ethnicity \\
\hline Engineer 1 & $\begin{array}{c}\text { Aerospace } \\
\text { Engineering }\end{array}$ & 21 & Male & Indian \\
\hline Engineer 2 & $\begin{array}{c}\text { Aerospace } \\
\text { Engineering }\end{array}$ & 22 & Female & White British \\
\hline Engineer 3 & $\begin{array}{c}\text { Aerospace } \\
\text { Engineering }\end{array}$ & 26 & Male & Any other mixed background \\
\hline Engineer 4 & $\begin{array}{l}\text { Mechanical } \\
\text { Engineering }\end{array}$ & 24 & Male & White British \\
\hline Engineer 5 & $\begin{array}{l}\text { Mechanical } \\
\text { Engineering }\end{array}$ & 21 & Male & White British \\
\hline Engineer 6 & $\begin{array}{l}\text { Mechanical } \\
\text { Engineering }\end{array}$ & 28 & Male & White British \\
\hline Engineer 7 & $\begin{array}{c}\text { Aerospace } \\
\text { Engineering }\end{array}$ & 21 & Male & Any other mixed background \\
\hline Engineer 8 & $\begin{array}{c}\text { Aerospace } \\
\text { Engineering }\end{array}$ & 20 & Female & Indian \\
\hline Engineer 9 & $\begin{array}{c}\text { Aerospace } \\
\text { Engineering }\end{array}$ & 22 & Male & Any other mixed background \\
\hline Engineer 10 & $\begin{array}{l}\text { Mechanical } \\
\text { Engineering }\end{array}$ & 21 & Male & White British \\
\hline Engineer 11 & $\begin{array}{c}\text { Aerospace } \\
\text { Engineering }\end{array}$ & 21 & Male & Any other black background \\
\hline Teacher 1 & Steiner & 19 & Female & White British \\
\hline Teacher 2 & Art and Design & 20 & Female & White British \\
\hline Teacher 3 & Steiner & 28 & Female & White British \\
\hline Teacher 4 & $\begin{array}{l}\text { Maths and } \\
\text { Science }\end{array}$ & 23 & Female & White British \\
\hline Teacher 5 & Humanities & 22 & Female & Any other black background \\
\hline Teacher 6 & $\begin{array}{l}\text { Maths and } \\
\text { Science }\end{array}$ & 20 & Female & White British \\
\hline Teacher 7 & $\begin{array}{c}\text { Language and } \\
\text { Literacies }\end{array}$ & 34 & Female & Any other mixed background \\
\hline Teacher 8 & $\begin{array}{l}\text { Maths and } \\
\text { Science }\end{array}$ & 19 & Female & White British \\
\hline Teacher 9 & $\begin{array}{l}\text { Maths and } \\
\text { Science }\end{array}$ & 20 & Female & Any other mixed background \\
\hline Teacher 10 & $\begin{array}{l}\text { Maths and } \\
\text { Science }\end{array}$ & 19 & Female & White British \\
\hline
\end{tabular}


Table 4: Characteristics of the Primary Schools Involved in the Paired Peer Mentors Project

\begin{tabular}{|c|c|c|c|c|}
\hline School & $\begin{array}{l}\text { Class } \\
\text { Year } \\
\text { Group }\end{array}$ & $\begin{array}{l}\text { Number of } \\
\text { Pupils }\end{array}$ & Type of School & $\begin{array}{l}\text { EU ENGINEER } \\
\text { Module Undertaken }\end{array}$ \\
\hline \multirow[t]{2}{*}{ School 1} & 6 & \multirow[t]{2}{*}{50} & \multirow{2}{*}{$\begin{array}{l}\text { Suburban } \\
\text { Academy Primary }\end{array}$} & \multirow[t]{2}{*}{ Electrical engineering } \\
\hline & 6 & & & \\
\hline School 2 & 6 & 39 & $\begin{array}{l}\text { Urban } \\
\text { Community } \\
\text { Primary School }\end{array}$ & $\begin{array}{l}\text { Mechanical - Adapted } \\
\text { opening bridge }\end{array}$ \\
\hline \multirow[t]{4}{*}{ School 3} & 5 & \multirow[t]{4}{*}{152} & \multirow{4}{*}{$\begin{array}{l}\text { Urban } \\
\text { Community } \\
\text { Primary School }\end{array}$} & \multirow[t]{4}{*}{ Aeronautical - Flight } \\
\hline & 5 & & & \\
\hline & 6 & & & \\
\hline & 6 & & & \\
\hline School 4 & 6 & 28 & $\begin{array}{l}\text { Suburban } \\
\text { Community } \\
\text { Primary School }\end{array}$ & Floating Platform \\
\hline
\end{tabular}


Figure 1: The Paired Peer Mentors Project.

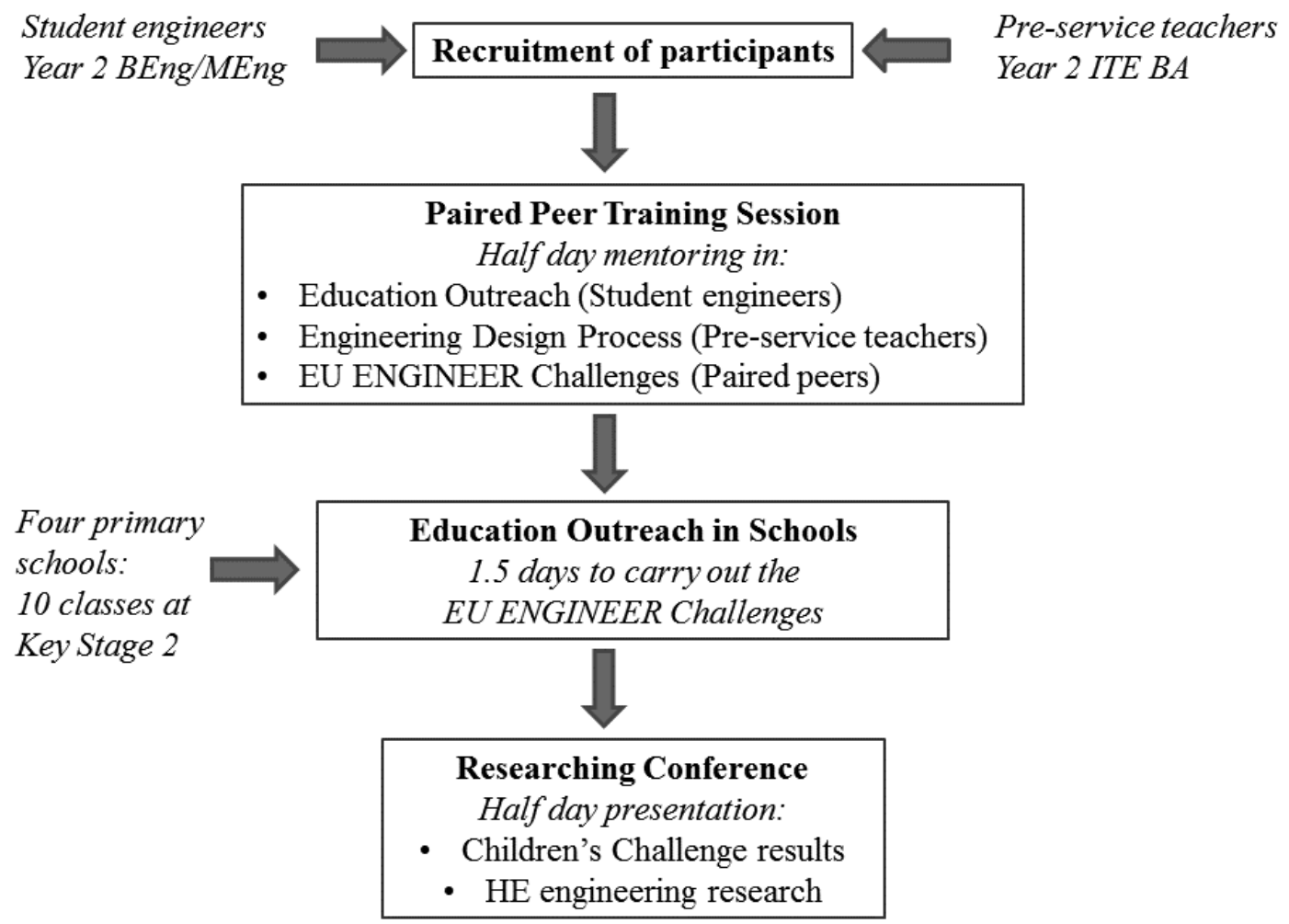


Figure 2: Feedback Ratings from Student Engineers and Pre-Service Teachers on the Paired Peer Mentors Project

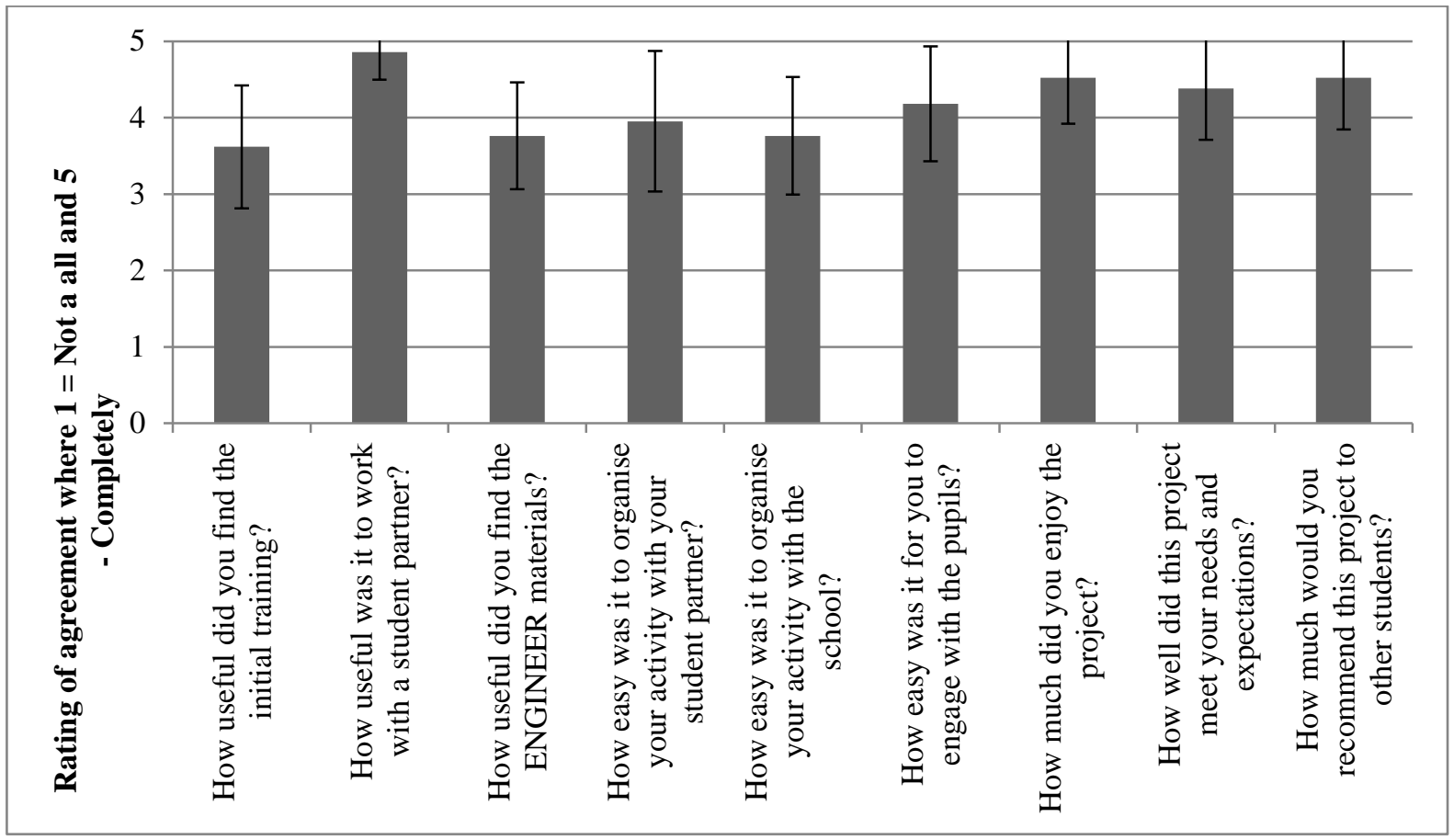

Figure 3: Perceived Self-Efficacy and Subject Knowledge Confidence

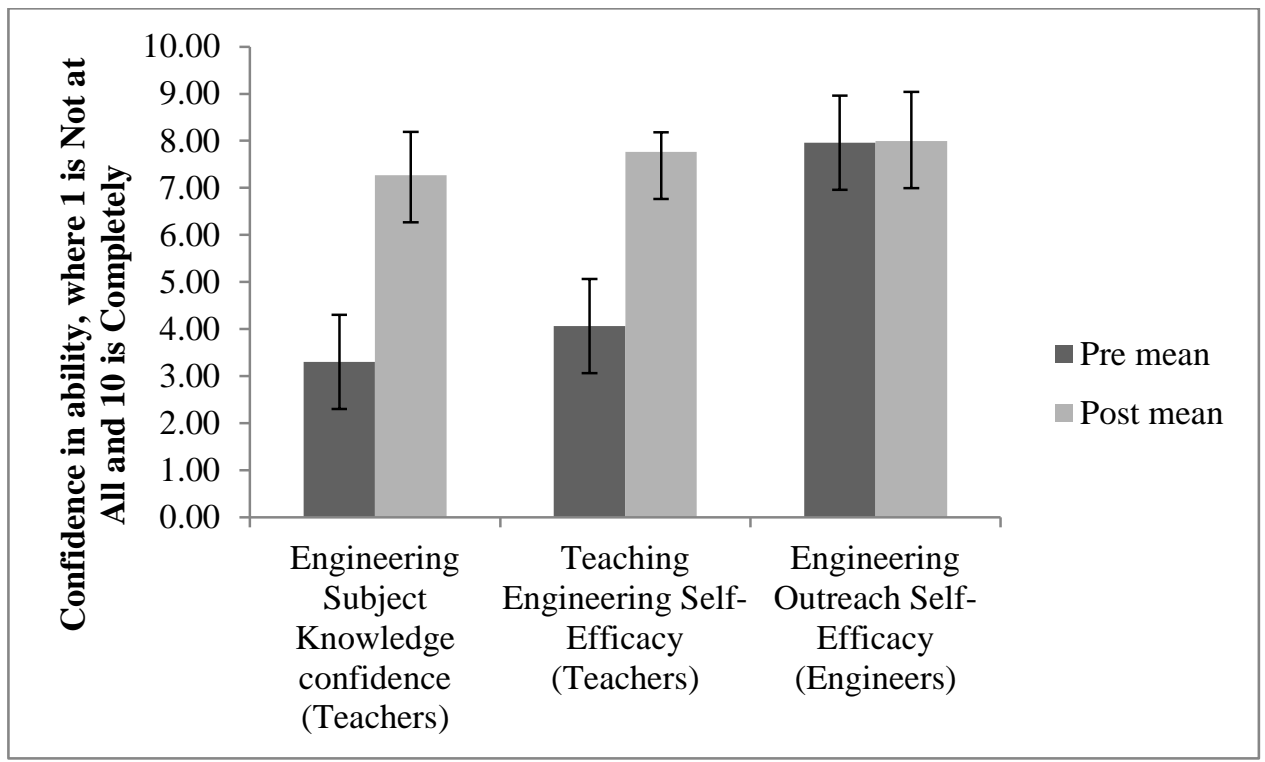


Figure 4: Words Used to Describe Teaching Science and Engineering by Pre-Service Teachers
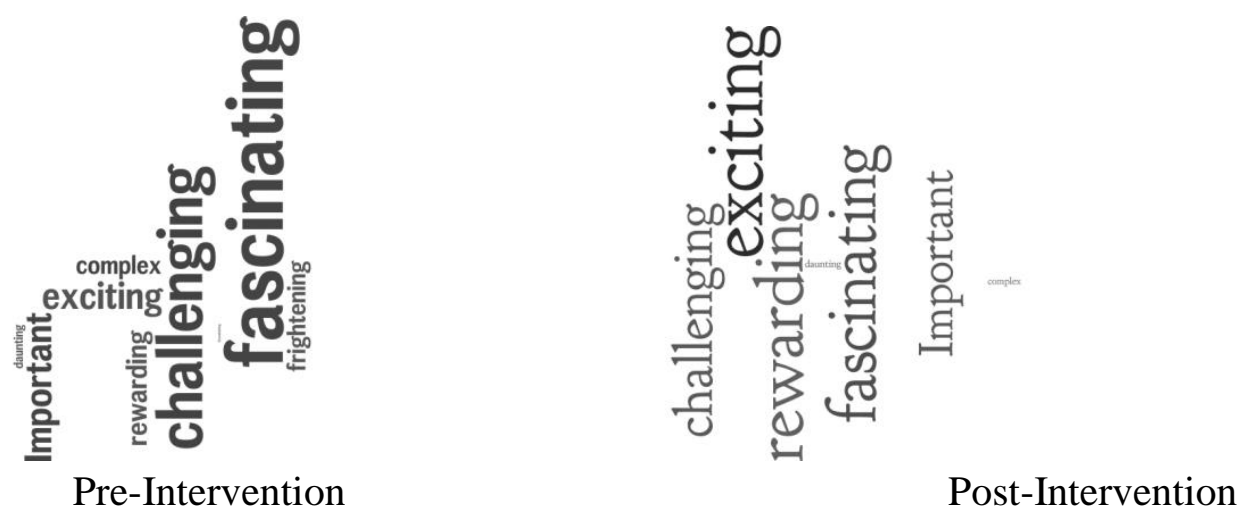


\section{References}

Archer, Louise, Jennifer Dewitt, Jonathan Osborne, Justin Dillon, Beatrice Willis, and Billy Wong. 2012. ""Balancing Acts": Elementary School Girls' Negotiations of Femininity, Achievement, and Science." Science Education 96: 967-989. doi:10.1002/sce.21031.

Bandura, Albert. 1997. "Self-Efficacy." Harvard Mental Health Letter 13 (9): 4. http://ezproxy.auckland.ac.nz/login?url=http://search.ebscohost.com/login.aspx?dir ect $=$ true $\& d b=f 5 h \& A N=9703260522 \&$ site $=$ ehost-live $\&$ scope $=$ site.

_ 2006. "Guide for Constructing Self-Efficacy Scales.” In Self-Efficacy Beliefs of Adolescents, 307-337.

Bandura, Albert, C Barbaranelli, G V Caprara, and C Pastorelli. 2008. "Self-Efficacy: The Exercise of Control." Child Development 72: 187-206. doi:10.1002/9780470479216.corpsy0836. http://www.ncbi.nlm.nih.gov/pubmed/15350854.

Bates, Alan B., Nancy Latham, and Jin-ah Kim. 2011. 'Linking Preservice Teachers' Mathematics Self-Efficacy and Mathematics Teaching Efficacy to Their Mathematical Performance." School Science and Mathematics 111: 325-333. doi:10.1111/j.1949-8594.2011.00095.x. http://doi.wiley.com/10.1111/j.19498594.2011.00095.x.

Bleicher, Robert E. 2004. "Revisiting the STEBI-B: Measuring Self-Efficacy in Preservice Elementary Teachers." School Science and Mathematics 104: 383. doi:10.1111/j.1949-8594.2004.tb18004.x. http://www.lib.ncsu.edu.proxied.lib.ncsu.edu.www.lib.ncsu.edu:2048/cgibin/proxy.pl?server=http://search.ebscohost.com.proxied.lib.ncsu.edu.www.lib.ncs u.edu:2048/login.aspx ?direct=true $\& d b=$ eric $\& A N=E J 708829 \&$ site=ehostlive $\&$ scope $=$ site.

Bleicher, Robert E., and Joan Lindgren. 2005. "Success in Science Learning and Preservice Science Teaching Self-Efficacy.” Journal of Science Teacher Education. doi:10.1007/s10972-005-4861-1.

Braun, Virginia, and Victoria Clarke. 2006. "Using Thematic Analysis in Psychology." Qualitative Research in Psychology 3 (2): 77-101.

Chue, S, and Y-J Lee. 2013. "The Proof of the Pudding? A Case Study of an 'At-Risk' Design-Based Inquiry Science Curriculum.” Research in Science Education 43: 2431-2454.

Cooper, H. 2014. Professional Studies in Primary Education. London, UK: SAGE Publications.

Cunningham, C. M. 2009. "Engineering Is Elementary."

Cunningham, C. M., C. P. Lachapelle, and J Hertel. 2012. "Research and Evaluation Results for the Engineering Is Elementary Project: An Executive Summary of the First Eight Years.” Boston, MA.

Davis, Chad E., Mark B. Yeary, and James J. Sluss. 2012. "Reversing the Trend of Engineering Enrollment Declines with Innovative Outreach, Recruiting, and 
Retention Programs.” IEEE Transactions on Education 55 (2): 157-163. doi:10.1109/TE.2011.2157921.

Department for Education. 2013. "Reform of the National Curriculum in England." https://www.gov.uk/government/publications/national-curriculum-in-englandprimary-curriculum.

Direito, Inês, Anabela Pereira, and A. Manuel de Oliveira Duarte. 2012. "Engineering Undergraduates' Perceptions of Soft Skills: Relations with Self-Efficacy and Learning Styles." Procedia - Social and Behavioral Sciences 55: 843-851. doi:10.1016/j.sbspro.2012.09.571. http://www.sciencedirect.com/science/article/pii/S1877042812040335.

Duffy, John, William Moeller, David Kazmer, and Linda Barrington. 2008. "ServiceLearning Projects in Core Undergraduate Engineering Courses." Internation Journal for Service Learning in Engineering 3: 18-41.

ENGINEER, EU. 2015. "Resources for Schools.” (http://www.engineerproject.eu/download/index.html).

Engineering Professors' Council. 2014. "20th Anniversary Awards." http://epc.ac.uk/20th-anniversary-awards-2014/.

EngineeringUK. 2015. "The State of Engineering." http://www.engineeringuk.com/EngineeringUK2015/EngUK_Report_2015_Intera ctive.pdf.

Flores, M. A., and Christopher Day. 2006. "Contexts Which Shape and Reshape New Teachers' Identities: A Multi-Perspective Study." Teaching and Teacher Education 22 (2): 219-232. doi:10.1016/j.tate.2005.09.002.

Fogg-Rogers, L, J Edmonds, and F Lewis. 2015. "Children as Engineers: Paired Peer Mentors in Primary Schools Final Report Summary July 2015.” London, UK. http://eprints.uwe.ac.uk/26053/.

Fogg-Rogers, L, C Wilkinson, and E Weitkamp. 2014. "Royal Society Education Outreach Training: Indicators for Impact in Education Outreach.” Bristol.

_. 2015. "Royal Society Education Outreach Evaluation."

Freeman, Scott, Sarah L Eddy, Miles McDonough, Michelle K Smith, Nnadozie Okoroafor, Hannah Jordt, and Mary Pat Wenderoth. 2014. "Active Learning Increases Student Performance in Science, Engineering, and Mathematics." Proceedings of the National Academy of Sciences of the United States of America 111 (23): 8410-5. doi:10.1073/pnas.1319030111.

http://www.pubmedcentral.nih.gov/articlerender.fcgi?artid=4060654\&tool=pmcent rez\&rendertype $=$ abstract.

Gonzalez, V M, J Goeppinger, and K Lorig. 1990. "Four Psychosocial Theories and Their Application to Patient Education and Clinical Practice." Arthritis Care \& Research 3 (3): 132-143.

http://ovidsp.ovid.com/ovidweb.cgi?T=JS\&CSC=Y\&NEWS=N\&PAGE=fulltext $\&$ $\mathrm{D}=$ med3\&AN=2285752.

Hewitt, D, and S. Tarrant. 2015. Innovative Teaching and Learning in Primary Schools. London, UK: SAGE Publications. 
Jeffers, Andrew T., Angela G. Safferman, and Steven I. Safferman. 2004.

"Understanding K-12 Engineering Outreach Programs." Journal of Professional Issues in Engineering Education and Practice. doi:10.1061/(ASCE)1052-

3928(2004)130:2(95).

Jung, Eunjoo, and Dent M. Rhodes. 2008. "Revisiting Disposition Assessment in Teacher Education: Broadening the Focus." Assessment \& Evaluation in Higher Education. doi:10.1080/02602930701773059.

Krathwohl, David R. 2002. “A Revision of Bloom's Taxonomy: An Overview.” Theory Into Practice. doi:10.1207/s15430421tip4104_2.

Lachapelle, C. P., C. M. Cunningham, T. J. Lee-St. John, M. Cannady, and K. Keenan. 2010. "An Investigation of How Two Engineering Is Elementary Curriculum Units Support Student Learning." In P-12 Engineering and Design Education Research.

Laursen, Sandra, Carrie Liston, Heather Thiry, and Julie Graf. 2007. "What Good Is a Scientist in the Classroom? Participant Outcomes and Program Design Features for a Short-Duration Science Outreach Intervention in K-12 Classrooms." CBE Life Sciences Education 6: 49-64. doi:10.1187/cbe.06-05-0165.

Louis S.Callahan, Janet Nadelson. 2011. "A Comparison of Two Engineering Outreach Programs for Adolescents." Journal of STEM Education: Innovations \& Research. Jan-Mar 201112 (1/2): 43-54.

Madhuria, G.V, V.S.S.N Kantamreddi, and L.N.S Prakash Gotetib. 2012. "Promoting Higher Order Thinking Skills Using Inquiry-Based Learning." European Journal of Engineering Education 37 (2): 117-123.

Marra, Rose M, Kelly a Rodgers, Demei Shen, and Barbara Bogue. 2009. "Women Engineering Students and Self-Efficacy: A Multi-Year, Multi-Institution Study of Women Engineering Student Self-Efficacy." Journal of Engineering Education 98: 27-38. doi:10.1002/j.2168-9830.2009.tb01003.x. http://jee.org/2009/january/5.pdf.

Martínez-Jiménez, Pilar, Lorenzo Salas-Morera, Gerardo Pedrós-Pérez, Antonio J. Cubero-Atienza, and Marta Varo-Martínez. 2010. “OPEE: An Outreach Project for Engineering Education.” IEEE Transactions on Education 53 (1): 96-104. doi:10.1109/TE.2009.2024931.

McKinnon, Merryn, and Rod Lamberts. 2013. "Influencing Science Teaching SelfEfficacy Beliefs of Primary School Teachers: A Longitudinal Case Study." International Journal of Science Education, Part B: 1-23. doi:10.1080/21548455.2013.793432. http://dx.doi.org/10.1080/21548455.2013.793432.

Mcmullan, Miriam, Ray Jones, and Susan Lea. 2012. "Math Anxiety, Self-Efficacy, and Ability in British Undergraduate Nursing Students." Research in Nursing and Health 35 (2): 178-186. doi:10.1002/nur.21460.

Michael, J A. 2006. "Where's the Evidence That Active Learning Works?" Advances in Physiology Education 30 (4): 159-167. doi:10.1152/advan.00053.2006.

Michael, J A, and H I Modell. 2003. Active Learning in Secondary and College Science Classrooms. Erlbaum Associates.

Mintzes, Joel J., Bev Marcum, Christl Messerschmidt-Yates, and Andrew Mark. 2012. 
"Enhancing Self-Efficacy in Elementary Science Teaching With Professional Learning Communities." Journal of Science Teacher Education.

doi:10.1007/s10972-012-9320-1.

Molina-Gaudo, Pilar, Sandra Baldassarri, Maria Villarroya-Gaudo, and Eva Cerezo. 2010. "Perception and Intention in Relation to Engineering: A Gendered Study Based on a One-Day Outreach Activity." IEEE Transactions on Education 53 (1): 61-70. doi:10.1109/TE.2009.2023910.

Murphy, Patricia, and Elizabeth Whitelegg. 2006. "Girls in the Physics Classroom: A Review of the Research on the Participation of Girls in Physics." London, UK. http://oro.open.ac.uk/6499/1/girls_and-physics.

National Coordinating Centre for Public Engagement. 2010. "Manifesto for Public Engagement." http://www.publicengagement.ac.uk/why-does-it-matter/manifesto.

Neale, Daniel C., Deborah Smith, and Virginia G. Johnson. 1990. "Implementing Conceptual Change Teaching in Primary Science.” The Elementary School Journal. doi:10.1086/461641.

Oakes, W., J. Duffy, T. Jacobius, P. Linos, S. Lord, W.W. Schultz, and A. Smith. 2002. "Service-Learning in Engineering." 32nd Annual Frontiers in Education 2. doi:10.1109/FIE.2002.1158178.

Ofsted. 2011. "Successful Science." https://www.gov.uk/government/uploads/system/uploads/attachment_data/file/413 802/Successful_science.pdf.

Owen, David, and Stephen Hill. 2011. "Embedding Public Engagement in the Curriculum: A Framework for the Assessment of Student Learning from Public Engagement."

Palmer, S. E., and R. A. Schibeci. 2012. "What Conceptions of Science Communication Are Espoused by Science Research Funding Bodies?" Public Understanding of Science. doi:10.1177/0963662512455295.

Perkins, John. 2013. "Professor John Perkins' Review of Engineering Skills." https://www.gov.uk/government/uploads/system/uploads/attachment_data/file/254 885/bis-13-1269-professor-john-perkins-review-of-engineering-skills.pdf.

Pickering, Melissa, Emily Ryan, Kaitlyn Conroy, Brian Gravel, and Merredith Portsmore. 2004. "The Benefit of Outreach to Engineering Students." In Proceedings of the 2004 American Society for Engineering Education Annual Conference \& Exposition.

RCUK. 2010. "Concordat for Engaging the Public with Research." http://www.rcuk.ac.uk/per/Pages/Concordat.aspx.

Rocard, M, P Csermely, D Jorde, D Lenzen, H Walberg-Henriksson, and V Hemmo. 2007. "Science Education Now: A Renewed Pedagogy for the Future of Europe." Brussels. http://ec.europa.eu/research/sciencesociety/document_library/pdf_06/report-rocard-on-science-education_en.pdf.

Royal Society. 2010. "The Scientific Century: Securing Our Future Prosperity." London, UK. https://royalsociety.org/policy/publications/2010/scientific-century/.

Stapleton, William, Bahram Asiabanpour, Harold Stern, and Hannah Gourgey. 2009. 
"A Novel Engineering Outreach to High School Education." In Proceedings Frontiers in Education Conference, FIE. doi:10.1109/FIE.2009.5350626.

Stilgoe, Jack, Simon J Lock, and James Wilsdon. 2014. "Why Should We Promote Public Engagement with Science?" Public Understanding of Science 23 (1) (January 1): 4-15. doi:10.1177/0963662513518154. http://pus.sagepub.com/content/23/1/4.abstract.

Van Driel, Jan H., Douwe Beijaard, and Nico Verloop. 2001. "Professional Development and Reform in Science Education: The Role of Teachers' Practical Knowledge." Journal of Research in Science Teaching 38 (2): 137-158. doi:10.1002/1098-2736(200102)38:2<137::AID-TEA1001>3.0.CO;2-U.

White, Paul J, Ian Larson, Kim Styles, Elizabeth Yuriev, Darrell R Evans, Jennifer L Short, Patangi K Rangachari, et al. 2015. "Using Active Learning Strategies to Shift Student Attitudes and Behaviours about Learning and Teaching in a Research Intensive Educational Context." Pharmacy Education; Vol 15 (2015) (July 27). http://pharmacyeducation.fip.org/pharmacyeducation/article/view/373.

Wilkinson, Clare, and Margarida Sardo. 2013. "Killer Facts for Informal Learning." http://www.wellcome.ac.uk/Education-resources/Education-andlearning/News/2013/WTP053966.htm.

Woolhouse, C., and M. Cochrane. 2009. "Is Subject Knowledge the Be All and End All? Investigating Professional Development for Science Teachers." Improving Schools. doi:10.1177/1365480209106431.

Yoon, So Yoon, Miles Griffin Evans, and Johannes Strobel. 2012. "Development of the Teaching Engineering Self-Efficacy Scale (TESS) for K-12 Teachers.” In Proceedings of the 119th American Society for Engineering Education Annual Conference and Exposition.

Zeldin, Amy L., Shari L. Britner, and Frank Pajares. 2008. "A Comparative Study of the Self-Efficacy Beliefs of Successful Men and Women in Mathematics, Science, and Technology Careers." Journal of Research in Science Teaching 45: 1036-1058. doi:10.1002/tea.20195. 